\title{
A conceptual framework towards understanding the relationship between a sport organization and its sponsors
}

\author{
Um framework conceitual para entender o \\ relacionamento entre uma organização esportiva e \\ seus patrocinadores
}

Fernando A. Fleury ${ }^{1}$

Rui David Marques ${ }^{2}$

\section{Resumo}

A parceria de patrocínio entre patrocinador e patrocinado, quando analisado o relacionamento business-to-business (B2B), foi pouco investigada. Entretanto, existem muitas pesquisas em outras áreas, o que proporciona pontos de vista muito bons para o assunto. A qualidade dessa parceria B2B é importante para criar, melhorar e manter a parceria, e é crítica para entender as correlações que acontecem nesse relacionamento. Portanto, é proposto um framework conceitual sobre a qualidade do relacionamento patrocinador-patrocinado no esporte, focando nas interações dinâmicas da parceria. Esse framework tenta mostrar a importância do relacionamento de marketing no contexto esportivo, mais especificamente quando se trata do patrocínio. Primeiro, é especificado no que consiste o relacionamento de marketing. Depois, é feita uma revisão sobre patrocínios e seus objetivos. Finalmente, argumenta-se como essas interações ocorrem no relacionamento dessa parceria e qual o papel de cada uma.

Palavras-chave: Patrocínio. Relacionamento B2B. Patrocínio Esportivo. Qualidade de Relacionamento.

Teacher at the Professional Master's Program in Administration - Sports Management at Nove de Julho University (UNINOVE) and researcher at Núcleo de EstudosemGestão do Esporte (GENOVE). Doctorate at FEA-USP/SP, in Economy of Organizations.Master in Administration at PUC-SP, with: Brand Management football clubs: how sport-marketing increases fan expenditure. Email - fleury00@gmail.com

2 Student of the Professional Master's Program in Administration - Sports Management (MPA-GE) - Nove de Julho University (UNINOVE) and Bachelor in Sports by the University of São Paulo (USP). Email - ruimarquess@gmail.com 


\section{Abstract}

The sponsorship partnership between sponsor and sponsored when analyzing the business-to-business (B2B) relationship has been little investigated.However, there is much research in other areas, which allows valuable views on the subject. The relationship quality in this $B 2 B$ partnershipis very important in creating, improving and maintainingthe partnership and it is critical to understand the correlations that happens in this relationship. Therefore, we propose a conceptual framework of the sport sponsor-sponsored relationship quality that focuses on the dynamic interactions of this relationship. This framework tries to highlight the importance of relationship marketing in the sport context and more specifically when one addresses sponsorships. First it is specified what relationship marketing is consisted of. Then provided an overview of sponsorships and their goals. Finally, it is argued how these interactions play in this relationship and what is the role of each in the partnership.

Keywords: Sponsorship. B2B relationship. Sport sponsorship. Relationship Quality.

\section{Introduction}

In order to survive in today's sport market,sport organization leaders have to determine how to effectively manage numerous challenges, like increasing costs, highly competitive markets and the exponential growth of new technology (GLADDEN; SUTTON, 2009; KIM; TRAIL, 2011). Even with the income growth, the cost of maintaining a professional structure within a sport organization has grown exponentially (KIM; TRAIL, 2011). Then the battle for the effectuation of the sponsorship betweenbig sport organizations is fierce and the costs involved are continuouslyrising, as the competitions become more and more true comercial battles (BENAZZI; BORGES, 2010).

Sport grew so much in the last decades that one cannot see it just as a leisure activity anymore. Today it is a source for business involving gambling, publicity, event organization and sponsorship for athletes, federations and sport organizations (BENAZZI; BORGES, 2010;SHANK, 2009). Still according to Shank (2009),sport today is understood as a popular global institution with annual revenue generation up to US\$400 billion. The sector represented $1.6 \%$ of the Brazilian GDP, what resembles about $\mathrm{R} \$ 67$ billion, presenting an annual yearly growth rate of $7.1 \%$ in the 
last five yearsovercoming the Brazilian growth rate that was $4.2 \%$ in the same period (PLURI, 2013).

In efforts to understand these challenges of the sport market, researchers have endorsed a change in the way marketing relationship is faced, going from the traditional exchange paradigm to a relationship approach (COUSENS; BABIAK; BRADISH, 2006; GLADDEN; SUTTON, 2009; HARRIS; OGBONNA, 2008). Along with this, marketing professionals have largely adopted strategies to build relationships (KIM; TRAIL, 2011). There are many beneficial reasons to adopt this type of approach when viewing the relationship sponsor/sponsored.

In a saturated and a highly competitive market, sport-marketing professionals need to redirect their main focus, expanding the acquisition of new consumers and maintaining the current ones. The growing need to maintain these customers is taking these professionals to embrace relationship marketing with the focus ofestablishinglong-termrelationships with these customers (KIM; TRAIL, 2011). We understand that the same procedure can be understood to the business-to-businessrelationship of the sponsor/sponsored, following the theory of relationship dynamics ofPalmatieret al.(2013).

With new technology emerging,sport marketing professionals are adoptingrelationship marketing. Historically relationship marketing was associated with stimulating some few key partners (KIM; TRAIL, 2011). Still according to the authors, today with newer technology it is easier and cheaper for marketing professionals to develop other forms of relationship with many types of partners. This affects the way sport organizations should relate with their sponsors.

Beyond all these challenges, the specific characteristics of the product sport allow necessary conditions for relationship marketing to be a fertile paradigm. This happens because sport organizations are often antropomorfisized and with this receive human personality qualities and characteristics, like honesty, trustiness, greed, resistance, etc. (HARRIS; OGBONNA, 2008). Furthermore, usually the main product of this market, the game/event, is produced, delivered and consumed at the same time 
(GLADDEN; SUTTON, 2009). Therefore, the interaction between all the involved in the relationship with sport is considered as part of the product. In addition, in the comercial exploration of sport presents itself in two agents: those that use sport only as a communication tool and those that have sport heading their business (BENAZZI; BORGES, 2010).

One understands that there is a constant need to apply relationship marketing in the partnership between sponsors and sponsored organizations in a way that they overcome the challenges related to sport organizations.In this article the focus are the sponsor companies and the sport organizations that receive these sponsorships as partners on the relationship. Based on literature we propose: the relationship marketing to the sport organization is a series of activities to establish, improve and maintain the relationship with the sponsor companies for the mutual benefit of the sport organizations and the sponsor companies. At the end of this study, the intention is to propose a conceptual framework to understand this relationship.

\section{Overview of relationship marketing}

Since Berry, in 1983, introduced the term relationship marketing in the service marketing area, relationship marketing grew very much(KIM; TRAIL, 2011). Both in academy and in practice this growth happened by the general belief that improved relationship marketing can build more consistent comercial relations leading to improvements in many sectors of the company such as sales, market share, profit etc (MORGAN; HUNT, 1994). Relationship marketing definitions have varied according to disciplines and context where the research is conducted(KIM; TRAIL, 2011). Researchers proposed numerous definitions trying to better understand the nature of relationship marketing (COUSENS; BABIAK; BRADISH, 2006; KIM; TRAIL, 2011; MORGAN; HUNT, 1994; PALMATIERet al.,2006;PALMATIER et al., 2013; SPEGORIN, 2010)

Although there is variation in the perspective and approaches about relationship marketing, usually they address three aspects of the relationship marketing: process, purpose and the involved (KIM; TRAIL, 
2011; PALMATIER, 2008; SHETH; PARVATIYAR, 2000). The definitions highlight the process aspect of relationship marketing and the main idea is that the process is characterized by the creation, improvement and maintenance of relationships (COUSENS; BABIAK; BRADISH, 2006; KIM; TRAIL, 2011). There is consensus that the purpose of relationship marketing is to achieve mutual benefits to all involved parties (PALMATIER et al., 2013; SPEGORIN, 2010). By its nature relationship marketing entails organizations that take part in this relationship, but the nature of these relationships is diverse and vary according to the type of partners (KIM; TRAIL, 2011).

Usually literature lists ten types of partnerships (KIM; TRAIL, 2011; MORGAN; HUNT, 1994;PALMATIER et al.,2006; SPEGORIN, 2010;): competitors, service providers, good suppliers, government, non-profit organizations, final customers, business units, intermediate customers, employees and functional departments. The present paper will focus on the non-profit sport organizations (the sport organizations that receive sponsorship) and in the sponsors, analyzing the business unit. We propose a framework, based on literature and in previous researches, which relationship marketing for the sponsored organization is a series of activities to establish, improve and maintain the relationship with its sponsors for the mutual benefit of the sport organizations and its sponsors.

According to Kim and Trail (2011), the amount of research in sports business about relationship marketing is small. However,there is much research in other areas, which allows valuable views on the subject. Palmatier (2013) builds even more on these theories of relationship marketing showing that they are dynamic relations, and not static, the way it was understood until then. We name three examples of studies in sport: Bee and Kahle (2006) who investigated the influence of relationship marketing in expected results and how three different levels of social influencemediated this relationship. Tower, JagoandDeery (2006) discussed how to develop and maintainsuccessful relationships between sport facilities and the sport organizations that use these facilities. Furthermore, Cousens, BabiakandBradish (2006) studied the strategic 
management ofrelationships between sport facilities and potential or existing sponsors.

\section{Overview of sponsorship}

In a wide definition, sponsorship can be explained as a comercial agreement between the sponsor and the object to be sponsored, where the sponsor gives economical support or some other type of support to establish an association between the sponsored object and its company (CORNWELL; ROY; STEINARD, 2001). Analyzing further the literature we find that the reasons for companies (sponsors) to support sportrelatesmainly to four elements associated with brand equity: raise the association with brand/product, raise the brand perceived quality, raise brand loyalty and improve brand relationship. Also others stated that motivation can be: improving sales, brand differentiation related to rivals and reasons related to causes that interest the company or companies that use sponsorships to achieve internal goals (ALEXANDRIS et al.,2008; CUNNINGHAM; CORNWELL; COOTE, 2009; FARRELLY; QUESTER, 2003; HENSELER; WILSON; WESTBERG, 2011; RIFON et al. 2004).

Within the sponsorship market, different sport organizations became sponsor objects that interest corporations for marketing strategies (O'REILLY; SÉGUIN, 2008). Still according to these authors, based on the reasons of the companies to sponsor the activity of the sponsored, sponsorship will draw benefits for both parties. The reasons that turn an object to be sponsored attractive to a sponsor depends on numerous factors linked to sport.

The partnership between sponsor and sponsored and the transfer associations that such partnership promotes can be used as a tool to achieve many different results (PICHOT; TRIBOU; O'REILLY, 2008). In the case of sponsorships there is very little that describes as one discrete way of exchange. On the contrary, the sport partnerships as sponsorship involve a series of interactions and inter-relationships. There are many related exchange processes that can happen simultaneously, or can happen consecutively, during time (FARRELLY; QUESTER, 2003). 


\section{A conceptual framework}

In this research we have an exploratory characteristic about subjects that surround relationship marketing between sponsor and sponsored. For understanding this paper, the sponsored aresport organizations and not exactly an athlete or a team. Looking to understand this relationship in a way to allowarisal of new ideas and hypothesis establishing analogies and comparing it with the theory. Our conceptual framework is built based in the integration of literature, common sense and practical experience, according to Eisenhardt (1989) to build theories and conceptual models. A theoretical essay can dismiss evidence, in the way of empirical proof where one submits hypothesis to testing. The coherence and probation of the theoretical essay reside in the coherence of the ideas of the essayists. Always remembering always to overcome the dichotomy between subjects and objects (BERTERO, 2011).

Part of this study is also a replica of papers published in international renowned journals, according to Rocha and Rocha (2007) that claim that the replica of studies realized by established authors and published in impact journals is a good starting point for the exercise of the method. Remembering that the replica, many times undervalued, is fundamental for the expansion of knowledge in many areas. The advantage of initial studies based on replica is, naturally, have a theoretical base and method where it is possible to rate the results.

In that sense we adopted for this paper a documental analysis using necessary secondary sources needed for any scientific research (MARTINS; THEOFILO, 2009).The object of this article was to adapt a series of concepts and knowledge presented by various authors in many areas, proposing a model that was adapted from a third area of knowledge. We used the conceptual model of Bass and Wind (1995) to include or exclude the constructs adopted in this article. A revision of the literature about sponsorships and relationship marketing and their constructs revealed that many authors in various disciplines proposed numerous constructs that we understand do not fit in the proposed model.For that reason many constructs of relationship marketing and 
sponsorship, mentioned in many papers were left out of this study. Then the constructs that we believe that fit this model and the rationalization for their inclusion explained. ÜsdikenandKieser (2004) integration vision takes in consideration the focus in the intersection and combining of the analyses and studies, particularly the ones focused on organizational processes.

\section{Conceptual Framework Diagram}

Figure 1 - Conceptual framework proposed by the authors for the relationship between sponsor and sponsored organization

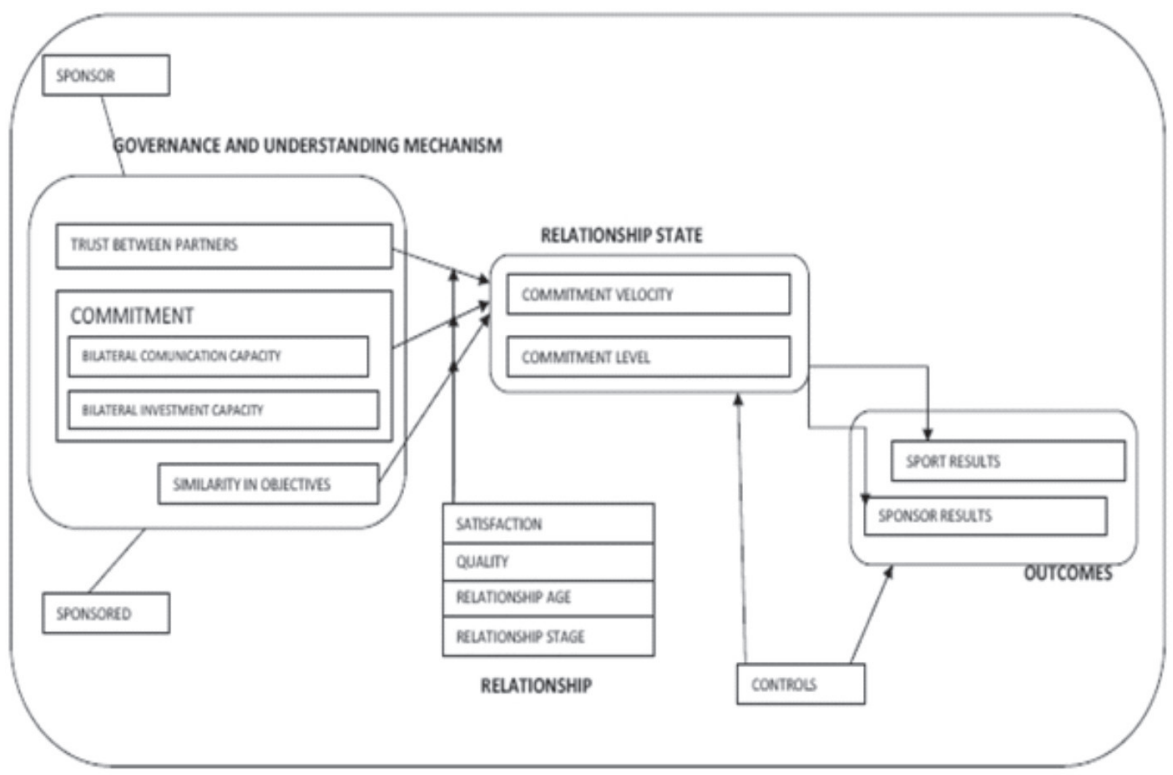

Source: Based inPalmatier (2013); Kim and Trail (2011) and Palmatier (2008) 


\section{Constructs of the proposed model}

\subsection{Mechanisms of governance and understanding between partners}

Trust between partners-is considered as a critical component in a successful relationship (COUSENS; BABIAK; BRADISH, 2006; KIM; TRAIL, 2011; MORGAN; HUNT, 1994; PALMATIER, 2008; PALMATIER et al., 2006; PALMATIER et al.,2013). Since Morgan and Hunt (1994) suggested that trust is based in the judgment of one partner of the relationship being reliable and having integrity. Moreover, trust reduces opportunistic behaviors and conflicts in commercial relations. In addition, trust influences many comercial objectives like market composition, sales and profit (KIM; TRAIL, 2011; PALMATIER et al.,2006)

Some researchers showed types of trust that are present in personal relationships like employee-employee (ZHANG et al.,2008) and sellerconsumer (PALMATIER et al.,2007). However, this relationship transfers to the relationship between companies (KIM; TRAIL, 2011).Moreover, this possible transfer in relationship is what interests this article to understand the business-to-business relationship between sponsor and sponsored.

Trust also precedes the development of the relationships because it creates an environment in which recognition and adaptation can occur (PALMATIER et al.,2013). With new opportunities that rise to create or join resources, trust raises the good will between the partners in taking more and bigger risks (MORGAN; HUNT, 1994; PALMATIER et al.,2006). Nevertheless, with time when the relationship ages, the positive link of trust can diminish. Then comes in commitment velocity, to keep explaining the relationship (PALMATIER et al.,2013).

As the relationship extends and ages, trust becomes less important because the interactions create routines, norms, lowers the perception of risk and less new opportunities become available (PALMATIER et al., 2013). So even being necessary, trust, with time, becomes less important for the maintenance or continuation of a mature relationship (POPPO; ZHOU; RYU, 2008). 
Commitment - like trust, commitment is been largely accepted as a vital component of the relationships(COUSENS; BABIAK; BRADISH, 2006; KIM; TRAIL, 2011; MORGAN; HUNT, 1994; PALMATIER et al.,2006;PALMATIER et al., 2013). Morgan and Hunt (1994) explain commitment as comercial partners that are in an ongoing relationship and it is important that one of them strive to keep this relationship. Commitment is one of the major characteristics that differentiate relationship partnership to functional partnerships (KIM; TRAIL, 2011).

Relationships, between individuals or companies, are not a static phenomenon (PALMATIER et al.,2013) and the positive commitment influences the agreement and the cooperative behavior. While negative commitment influences the propensity to separation (MORGAN; HUNT, 1994). Then we find researches that suggest two types of existent capacities in companies that are critical for a sustainable relationship to flourish (PALMATIER et al.,2007). First, the partners should communicate effectively to identify new opportunities and create increased value that supports and holds together a relationship. Then commercial partners should invest to explore identified opportunities. This is the reason why bilateral investment capacities and bilateral communication capacities are so important in a relationship (PALMATIER et al.,2013).

Bilateral communication and investment capacity - The communication between partners affects positively the relationships revealing similar points, solving problems, giving ways to find and align objectives and identifies opportunities to create value, improve revenue and reduce costs (ANDERSON, 2007; PALMATIER et al.,2013; JAP).

Communication capacities between partners (sponsor and sponsored) are critical because of the complexity that exists in value creation, that needs to be in constant adaptation. Problems in value creation that can promote a weak structure and have obscure objectives can grow producing unexpected results that are difficult to interpret (AARIKKA-STENROOS; JAAKKOLA, 2012). Through the capacity of partners to exchange information, they can create value finding processes and with it adapting quickly, alternating responsibilities to particular 
activities, improving problem solving, aligning better the objectives and reducing the costs of monitoring the partnership (ULAGA; EGGERT, 2006). Coordination and effective reaction is necessary to have updated knowledge. These communication capacities become more important in turbulent markets (PALMATIER et al.,2013).

When investigating investment capacity, unlike trust, it is expected that these investment capacities grow while the relationship ages (PALMATIER et al.,2013). Relationshipsusually start identifying and exploring simple opportunities. These easier opportunities allow the partners to evaluate the new relationship and usually need little investment (KANG; MAHONEY; TAN, 2009). When the relationship ages and deepens the majority of the easy opportunities will have been explored. Leading the partners to seek more intense and harder investment opportunities that leverage the bilateral investment capacities. Furthermore, the longer the relationship, more trust the partners will have on each other that makes the relationship endure (PALMATIER et al.,2013). Similar with the communication capacities, the positive impact of the investment capacities should be higher in turbulent markets (FANG; PALMATIER; STEENKAMP, 2008).

The sport market is very turbulent, inclined to constant changes. For Shilbury (2012),more than in most industries, the results in sport competitions are shown weekly or daily. With technology today allowing quick access to these results anywhere in the world. A sport organization should work wary to maintain itself economically and results healthy to maintain itself competitive (VIANA DE FREITAS; FONTES FILHO, 2011).

Similarity in objectives - is another important point in a relationship. Morgan and Hunt (1994) define itas similar cultures, values and objectives between organizations. The similarity between people or organizations can be an indicator that the relationship partner can help to achieve important objectives and has shown that it affects positively relationship mediators. (DONEY; CANNON, 1997; PALMATIER et al.,2006).At this stage, communication influences because the objectives of the partnership can be, by the nature of its activities, not exactly the 
same. At this moment good communication for mutual understanding is important.

\section{Relationship}

We understand that relationship satisfaction, relationship quality (PALMATIER et al.,2006), relationship age and relationship stage will influence the commitment level and commitment velocity of this relationship (PALMATIER et al., 2013).

Relationship satisfaction and relationship quality are highly influenced by the performance in relation to the objective which is a dimension composed by the strength of the relationship (PALMATIER et al.,2006). The authors still show the significant influence of loyalty in service relationships, communications channels and commercial markets, such as performance in these markets. They also suggest a bigger impact in situations where the relationships are more critical to succeed.

For Palmatieret al. (2006) selection and training in a relationship are essential. Acquaintance, communication and similarity are the most efficient strategies to establish relationships. Other important attributesfor value creation in this relationship are abilities and knowledge (VARGO; LUSCH, 2004). We understand that abilities are the biggest investment and counterpart of the sponsored to the sponsor.

Palmatieret al. (2013) found scientific proof that the three relationship dynamic perspectives (stage, age and velocity) that follow the same growth path. Beyond the critical abilities and capacities, there should be mechanisms to direct the risks and rewards of the relationship, that then allow the partners to achieve the desired results ( $\mathrm{GHOSH}$; $\mathrm{JOHN}, 1999$ ). At this stage comes in consideration integrity, trust and security. Here is when age, or duration, of the relationship becomes a moderator variable of the bilateral communication and investment capacity of both collaborates (PALMATIER et al., 2013). 
One then needsto take in consideration another moderator the relationship stage; this is not linear and depends in factors as commitment velocity and commitment level to evolve. So two relationships of the same duration (age) might not be at the same stage (PALMATIER et al., 2013). In addition, trust has a very important role, again, as it is very expensive and consumes a great amount of time to re-write contracts and monitor contract performance in dynamic market conditions, but trust allows partners to adapt quicker (DYER; SINGH, 1998).

\section{Relationship state}

At thispoint, we understand that it is possible to fit, in a way to answer our ideas, the dynamic relationship theory ofPalmatieret al.(2013) that takes in consideration commitment level and commitment velocity to define the state of a relationship. While the phases suggest a linear progression through which relationships grow, we emphasize again that, those processes that build relationships are dynamic by nature (COUSENS; BABIAK; BRADISH, 2006; PALMATIER et al., 2013).

These studies of Palmatieret al.(2013) were based in researches seller/consumer. However, we understand, by experience and bibliographical research mentioned before, that constructs can be applied to this relationship sponsor/sponsored that we are showing in this article. The same authors mention, when starting to define commitment velocity, which relationships happen between individuals or companies, and they are a dynamic phenomenon.

Having defined the term relationship velocity as the changes that encompass relationship direction and velocity, the results of the research show that trust, communication and investment capacity influence commitment velocity. These capacities influence commitment velocity of the opportunities of the partnership allowing the continuous understanding through communication.In addition, the exploration and exploitation of these opportunities and commitment is the essential ingredient of the long-term relationships (PALMATIER et al. 2013). The congruence of all these factors will lead to better results. 


\section{Outcomes}

The expected outcomes by the partners are different because of the different nature of the businesses of the partners (sponsor/ sponsored). In addition, because of that, the interactions between the sport organizations and its partners extends beyond simply the sale of a menu of assets like audience access, publications visibility and collateral material (COUSENS; BABIAK; BRADISH, 2006).

The sponsored seeks, and consequently offers the sponsor, sport results. Expects these results to be always better, in an upsweep. The bilateral investment capacity, or counterpart of the sponsored, is understood to be this capacity to keep improving sport results.Presenting better and more trained athletes, achieving better results andgiving a better return to the money invested by the sponsor.

The result that the sponsor looks for can be various, and depending on the nature of the business of the company and the goals that it has at that moment in time. This goal can change during the duration of the relationship. Some results searched by the sponsors, already stated,couldbe raise brand or product loyalty, raise the perceived brand quality and raise brand relationship. Besides other reasons, like sales growth, brand differentiation etc.

\section{Summary and future research}

Create, improve and maintain good relationships are fundamental principles of sport marketing. Also it is very interesting the idea that sport organizations can create a competitive advantage implementing effective strategies of relationship marketing and improving its ties with partners, other than simply focus on ticket sales and short term results (GLADDEN; SUTTON, 2009). It is essential to understand the relationship quality between partners to better develop and execute marketing strategies. Independent of the theoretical and practical importance of relationship marketing there is little research about the relationship sponsor/ sponsored. In an attempt to shorten this gap, we propose this framework. 
This framework tries to highlight the importance of relationship marketing in the sport context and more specificallywhen addressing sponsorships. Bringing out recent theories that deal with this relationship in a dynamic scheme,when writing this article we tried to provide theoretical grounding to understand the central constructs of the relationship sponsor/sponsored and some potential moderators that join the relationship between them. In addition, our conceptual model postulates that the commitment level and commitment velocity of Palmatier et al. (2013) influences the results.

The clear understanding of internal and external factors that motivate the creation and evolution of the relationship will help establish a strong tie between corporate and sport partners. The need to maintain one attentive to the importance of the "marriage" of values, image, beliefs and strategies of both partners has to be remembered. Here we tried to provide another tool for sport managers to understand the importanceof a good relationship with their sponsors that can leverage their businessto-business relationship in this competitive environment of today. Finally, tried to give a contribution to expand the literature of the relationship companies-sport in sport marketing.

An interesting theme for future research is to test the proposed model. Making the necessary adjustments that empirical research can point out. A further interesting topic is the applicability of the conceptual model to other general contexts of sponsorships and not only businessto-business relationships.

\section{References}

AARIKKA-STENROOS, Leena; JAAKKOLA, Elina. Value co-creation in knowledge intensive business services: A dyadic perspective on the joint problem solving process. Industrial Marketing Management, v. 41, n. 1, p. 15-26, January 2012.

ALEXANDRIS, K. et al. The influence of spectators' attitudes on sponsorship awareness: a study in three different leisure events. Managing Leisure, v. 13, n. 1, p. 1-12, January 2008. 
BASS, Frank M.; WIND, Jerry. Introduction to the special issue: empirical generalizations in marketing. Marketing Science, v. 14, n. 3, supplement, p. G1-G5, August 1995.

Bee, C. C.; Kahle, L. R. Relationship marketing in sports: A functional approach. Sport Marketing Quarterly, v. 15, n. 2, p. 101, 2006.

BENAZZI, João Renato de Souza Coelho; BORGES, Cláudio Neves; Emoção, Exposição e Vendas: análise do patrocínio realizado por marcas de artigos esportivos no futebol brasileiro. In:Simpósio de Excelência em Gestão e Tecnologia, VI, 2009. Resende-RJ: Associação Educacional Dom Bosco (AEDB), outubro 2009.

BERTERO, Carlos Osmar. Réplica 2-o que é um ensaio teórico? Réplica a Francis Kanashiro Meneghetti. Revista de Administração Contemporânea, Rio de Janeiro, v. 15, n. 2, p. 338-342, mar./abr. 2011.

CORNWELL, T. Bettina; ROY, Donald P.; ROY, Donald P. Exploring managers' perceptions of the impact of sponsorship on brand equity. Journal of Advertising, v. 30, n. 2, p. 41-51, 2001.

COUSENS, Laura; BABIAK, Kathy; BRADISH, Cheri L. Beyond sponsorship: Re-framing corporate-sport relationships. Sport Management Review, v. 9, n. 1, p. 1-23, 2006.

Cunningham, S.; Cornwell, T. B.; Coote, L. V. Expressing identity and shaping image: The relationship between corporate mission and corporate sponsorship. Journal of Sport Management, v. 23, n. 1, p. 65-86, February 2009.

MARTINS, Gilberto de Andrade; THEÓPHILO, Carlos Renato. Metodologia da investigação científica para ciências sociais aplicadas. São Paulo: Atlas, p. 95, 2007.

DONEY, Patricia M.; CANNON, Joseph P. An examination of the nature of trust in buyer-seller relationships. The Journal of Marketing, v. 61, n. 2, p. 35-51, April 1997. 
DYER, Jeffrey H.; SINGH, Harbir. The relational view: cooperative strategy and sources of interorganizational competitive advantage. Academy of management review, v. 23, n. 4, p. 660-679, October 1998.

EISENHARDT, Kathleen M. Building theories from case study research. Academy of management review, v. 14, n. 4, p. 532-550, October 1989.

FANG, Eric; PALMATIER, Robert W.; STEENKAMP, Jan-Benedict EM. Effect of service transition strategies on firm value. Journal of Marketing, v. 72, n. 5, p. 1-14, September 2008.

FARRELLY, Francis; QUESTER, Pascale. The effects of market orientation on trust and commitment: The case of the sponsorship business-to-business relationship. European Journal of Marketing, v. 37, n. 3/4, p. 530-553, 2003.

GLADDEN, J. M.; SUTTON, W. A. Marketing principles applied to sport management. Principles and practice of sport management, p. 3653, Canadá: Jones and Barlett Publishes International, 2005, p.36-53

GHOSH, Mrinal; JOHN, George. Governance value analysis and marketing strategy. The Journal of Marketing, v. 63, special issue, p. 131-145, 1999.

HARRIS, Lloyd C.; OGBONNA, Emmanuel. The dynamics underlying service firm-customer relationships: Insights from a study of English Premier League soccer fans. Journal of Service Research, v. 10, n. 4, p. 382-399, May 2008.

HENSELER, Jörg; WILSON, Bradley; WESTBERG, Kate. Managers' perceptions of the impact of sport sponsorship on brand equity: Which aspects of the sponsorship matter Most?. Sport marketing quarterly, v. 20, n. 1, p. 7-21, 2011.

JAP, Sandy D.; ANDERSON, Erin. Testing a life-cycle theory of cooperative interorganizational relationships: Movement across stages and performance. Management Science, v. 53, n. 2, p. 260-275, February 2007. 
KANG, Min-Ping; MAHONEY, Joseph T.; TAN, Danchi. Why firms make unilateral investments specific to other firms: The case of OEM suppliers. Strategic Management Journal, v. 30, n. 2, p. 117-135, February 2009. Kim, Yu. K.; Trail, Galen. A conceptual framework for understanding relationships between sport consumers and sport organizations: $A$ relationship quality approach. Journal of Sport Management, v. 25, n. 1, p. 57-69, January 2011.

MORGAN, Robert M.; HUNT, Shelby D. The commitment-trust theory of relationship marketing. The journal of marketing, v. 58, n. 3, p. 20-38, July 1994.

O'REILLY, Norm; SÉGUIN, Benoit. Sport marketing: A Canadian perspective. Local : Nelson Education, 2008.

PALMATIER, Robert W. et al. Factors influencing the effectiveness of relationship marketing: a meta-analysis. Journal of marketing, v. 70, n. 4, p. 136-153, October 2006.

PALMATIER, Robert W. et al. Use of relationship marketing programs in building customer-salesperson and customer-firm relationships: Differential influences on financial outcomes. International Journal of Research in Marketing, v. 24, n. 3, p. 210-223, 2007.

PALMATIER, Robert W. Interfirm relational drivers of customer value. Journal of Marketing, v. 72, n. 4, p. 76-89, 2008.

PALMATIER, Robert W. et al. Relationship velocity: Toward a theory of relationship dynamics. Journal of Marketing, v. 77, n. 1, p. 13-30, 2013.

PICHOT, Lilian et al. Sport sponsorship, internal communications, and human resource management: An exploratory assessment of potential future research. International Journal of Sport Communication, v. 1, n. 4, p. 413-423, 2008.

CONSULTORIA, Pluri. O PIB do esporte brasileiro 2012. Disponível em: <http://www.pluriconsultoria.com.br/uploads/relatorios/PIB\%20 Esporte>. Acesso em: 10 jun. 2013. 
POPPO, Laura; ZHOU, Kevin Zheng; RYU, Sungmin. Alternative origins to interorganizational trust: An interdependence perspective on the shadow of the past and the shadow of the future. Organization Science, v. 19, n. 1, p. 39-55, 2008.

RIFON, Nora J. et al. Congruence effects in sponsorship: the mediating role of sponsor credibility and consumer attributions of sponsor motive. Journal of Advertising, v. 33, n. 1, p. 30-42, 2004.

DA ROCHA, Angela; ROCHA, Everardo. Paradigma interpretativo nos estudos de consumo: retrospectiva, reflexões e uma agenda de pesquisas para o Brasil. RAE-Revista de Administração de Empresas, v. 47, n. 1, p. 71-80, jan./mar. 2007.

SHANK, Matthew D. Sports marketing: a strategic perspective. 5. ed. São Paulo: Pearson/Prentice Hall, 2005.

SHETH, Jagdish; PARVATIYAR, Atul. Handbook of relationship marketing. California: Sage Publications, 1999.

SHILBURY, David et al. Competition: The heart and soul of sport management. Journal of sport management, v. 26, n. 1, p. 1-10, 2012.

Spegorin, Maura. A. D. C. Marketing de relacionamento por meio de construtos relacionais: um estudo de caso no setor de comércio exterior. 2010. 202 f. Dissertação (Mestrado em Administração de Empresas). Fundação Instituto Capixaba de Pesquisas em Contabilidade, Economia e Finanças (FUCAPE), Vitória/ES, 2010.

Tower, John; Jago, Leo; Deery, Margaret. Relationship marketing and partnerships in not-for-profit sport in Australia. Sport Marketing Quarterly, v. 15, n. 3, p. 167-180, 2006.

ULAGA, Wolfgang; EGGERT, Andreas. Value-based differentiation in business relationships: gaining and sustaining key supplier status. Journal of Marketing, v. 70, n. 1, p. 119-136, 2006.

ÜSDIKEN, Behlül; KIESER, Alfred. Introduction: History in organisation studies. Business History, v. 46, n. 3, p. 321-330, July 2004. 
VARGO, Stephen L.; LUSCH, Robert F. Evolving to a new dominant logic for marketing. Journal of marketing, v. 68, n. 1, p. 1-17, January 2004.

VIANA DE FREITAS, Helio; FONTES FILHO, Joaquim Rubens. A Governança Corporativa nos Clubes de Futebol: um Estudo de Caso sobre o Clube de Regatas do Flamengo. Revista ADM. MADE, v. 15, n. 3, p. 39-60, set./dez. 2012.

ZHANG, Ann Yan et al. How do I trust thee? The employee-organization relationship, supervisory support, and middle manager trust in the organization. Human Resource Management, v. 47, n. 1, p. 111-132, February 2008.

Artigo recebido em: 16/10/2014

Aprovado em: 10/12/2014 